\title{
Trans People and the Church of England: Disadvantage and Microaggressions
}

\author{
Rob Clucas
}

\begin{abstract}
:
In this article, I discuss the situation of trans people within the Church of England. I outline instances of legal and institutional discrimination in the following situations: the Equality Act 2010 in the context of employment, promotion and training; trans candidates for ordination; and marriage involving (a) trans person(s). I discuss some theology relating to this discrimination. I explain the impact of disadvantage and discrimination for minority groups with reference to minority stress, and clarify the microaggressive messages contained in differential institutional treatment for trans people. I suggest that the harm done by Church discrimination against trans people is real and significant, and ought to be recognized and addressed.
\end{abstract}

KEYWORDS:

CHURCH OF ENGLAND; DISCRIMINATION; DISCRETION; EQUALITY ACT 2010; LGBT; MARRIAGE; MICROAGGRESSIONS; MINORITY STRESS; ORDINATION; PREJUDICE; TRANS; TRANSGENDER

\section{Introduction: Trans issues, the institutional Church, and the law}

Most readers will be aware of the differential treatment afforded to lesbian, gay and bisexual (LGB) people by the Church of England. What is not so obvious is the position of trans people (the ' $\mathrm{T}$ ' in LGBT). In this article, I aim to make this clearer, not only with respect to obvious instances of discrimination - which are legal and institutional - and its effects, but also with respect to the microaggressive messages hidden within these discriminatory practices that make the Church a difficult and unsafe place for many trans people.

I begin with a few notes regarding terminology. By 'trans people', I mean people whose gender identity is different in some way to the sex they were assigned, and gender they were assumed to be, at birth. This is in contrast to 'cis' or 'cisgender' people - people who are comfortable with the sex, and corresponding gender identity, they were assigned at birth. 
Since the coming into force of the Gender Recognition Act 2004, it has been possible for a person assigned female but identifying as male, or assigned male but identifying as female, to change their legal sex and birth certificate. Some trans people obtain the Gender Recognition Certificate (GRC) necessary for change of legal sex; other trans people identify, live, and present themselves as their preferred gender without doing so. This is relatively easy to do: names, and gender markers on passports and driving licences can be changed without a GRC. It is not necessary to have any physical or medical treatment in order to obtain a GRC; social transition and the intention to live permanently in the 'opposite' ('acquired') gender than that assigned at birth, is required. Moreover, the GRC has become practically less important since the possibility of same-sex marriage: for example, before the Marriage (Same Sex Couples) Act 2013, a trans man without a GRC was unable to marry his female partner, as he was still legally female. Now they may marry. The 2013 Act also resolves the problem that used to face trans people who were married before one party transitioned: a GRC may now be acquired without divorce, as the marriage of same sex couples is lawful.

Other trans people reject the binary model of male-female, man-woman, or reject gender in some way (perhaps by regarding themselves as not having a gender identity at all). Nonbinary people are the least recognized in our society and the Church, and find themselves most often at variance with society's expectations and prescriptions. ${ }^{1}$ But this experience of repeated divergence, difference and conflict is present in every trans person's encounter with the rules of broader society and the Church of England. In this article, I aim to clarify some of the difficulties in being trans in an environment that privileges cis gender, and explain the ways in which the Church of England as an institution contributes to and perpetuates this damage and harm. This clarification draws on the research available on trans people and religious environments; accounts of trans people published in hard copy and on the internet; and my own experience as a person transitioning whilst a member of the Church of England.

First, I outline briefly the principal ways in which trans people are disadvantaged by the institutional Church and its legal environment. Next, I examine the theological implications of

\footnotetext{
${ }^{1}$ For further discussion, see Rob Clucas and Stephen Whittle, "Nonbinary People and the Law," in Genderqueer and Non-Binary Genders, ed. Christina Richards, Walter Bouman, and Meg John Barker (Houndmills, Basingstoke, Hampshire: Palgrave Macmillan, forthcoming) and Christie Elan-Cane, "Fighting for Legal and Social Recognion Outside the Gendered Social Structure," in Trans in the Twenty First Century: Concerning Gender Diversity, ed. Alice Purnell and Jed Bland (London: Beaumont Trust, 2011), pp. 130-39.
} 
this disadvantage, and the impact of this on trans people's health. I then describe the concept of microaggressions developed by Derald Wing Sue and his colleagues, ${ }^{2}$ and reconsider the Church environment with this in mind. Finally, I conclude with a plea that all members of the Church take this discriminatory environment seriously and consider its cost. Much of what I write here can be applied to LGB people also; my focus here is simply on clarifying trans issues.

\section{Trans issues, the Institutional Church, and the law}

A popular view understands law to be about statutes and cases, judges and other legal officials. This is known as a formal conception of law. In contrast, many legal theorists, myself included, see law as a functionaß 'enterprise of subjecting human conduct to the governance of rules'. ${ }^{4}$ On this view, whether a rule-maker is a state legislature or General Synod, and whether formal rules are called 'statutes,' 'measures,' 'Handbook,' or 'official teaching' is unimportant; what matters is whether they fulfil a relevantly similar function. For this reason, though I discuss institutional regulation and state regulation separately as needed, I do not regard them as being significantly conceptually different as forms of law-making. ${ }^{5}$

\section{Overtly less favourable treatment of trans people}

The following instances are examples of permitted discrimination within the legal and institutional framework of the Church, where it is lawful to treat a trans person less favourably than a cis person.

\footnotetext{
2 Derald Wing Sue et al., "Racial Microaggressions in Everyday Life: Implications for Clinical Practice.," American Psychologist 62, no. 4 (2007): 271-86, doi:10.1037/0003-066X.62.4.271; Derald Wing Sue, Microaggressions in Everyday Life: Race, Gender, and Sexual Orientation (Hoboken, New Jersey: John Wiley and Sons Inc., 2010); Kevin L. Nadal, Avy Skolnik, and Yinglee Wong, "Interpersonal and Systemic Microaggressions Toward Transgender People: Implications for Counseling," Journal of LGBT Issues in Counseling 6, no. 1 (January 2012): 55-82, doi:10.1080/15538605.2012.648583.

${ }^{3}$ John N. Adams and Roger Brownsword, Understanding Law, 4th ed. (London: Thompson: Sweet and Maxwell, 2006), chap. 1; K. N. Llewellyn, "The Normative, the Legal, and the Law-Jobs: The Problem of Juristic Method," The Yale Law Journal 49, no. 8 (June 1940): 1355, doi:10.2307/792545; K. N. Llewellyn and E. Adamson Hoebel, The Cheyenne Way: Conflict and Case Law in Primitive Jurisprudence (Civilization of American Indian), New (Oklahoma: University of Oklahoma Press, 1941).

${ }^{4}$ Lon L. Fuller, The Morality of Law, Revised (New Haven and London: Yale University Press, 1969), p. 96.

${ }^{5}$ The import of this will become clearer in the discussion on relationship recognition, below.
} 


\section{Employment, promotion, and training}

The Equality Act 2010 provides safeguards for people with 'protected characteristics', including gender reassignment - a category that includes trans men and trans women, or people with a trans history, though it may exclude nonbinary people - from discrimination, victimization and harassment. Notwithstanding this, there are exceptions in Schedule 9 of the Act 'for the purposes of an organised religion' in relation to employment, promotion and training. These exceptions make it possible to require someone not to be a transsexual person (Schedule 9 paragraph 2(4)(b)), where being transsexual is contrary to the doctrines of a religion (Schedule 9 paragraph 2(5)), or so as to avoid conflict with the 'strongly held religious convictions of a significant number of the religion's followers' (Schedule 9 paragraph 2(6)). ${ }^{6}$ Either the person to whom the Church applies this principle must be transsexual, or the Church may have reasonable grounds for believing that that person is transsexual.

This means that the Church may, but is not obliged to, treat a transsexual person less favourably than a cis person, in relation to employment, training and promotion.

The general legal question of whether a clergyperson is an employee of the Church of England is complicated and context-specific - see Sharpe $v$ The Bishop of Worcester. ${ }^{7}$ For the purposes of the Equality Act, however, ministers of religion are employees to whom Schedule 9 paragraph 2 applies. ${ }^{8}$ Persons employed by the Church for purposes other than that of an organized religion, such as an accountant, are protected by the ordinary non-discrimination provisions of the main body of the Equality Act.

\section{Ordination}

Trans candidates for ordination will be aware of the differential provision in the Diocesan Directors of Ordination Handbook:

\footnotetext{
${ }^{6}$ For further discussion of these points, see R. Clucas, "Religion, Sexual Orientation and the Equality Act 2010: Gay Bishops in the Church of England Negotiating Rights Against Discrimination," Sociology 46, no. 5 (October 1, 2012): 936-50, doi:10.1177/0038038512451533.

7 Sharpe v The Bishop of Worcester (EWCA (Civ) April 30, 2015); Russell Sandberg and Frank Cranmer, "Not a Sharpe Turn: A Note on Sharpe v Bishop of Worcester |," Law \& Religion UK, May 2, 2015, http://www.lawandreligionuk.com/2015/05/02/not-a-sharpe-turn-a-note-on-sharpe-v-bishop-ofworcester/\#more-19156.

8 Equality and Human Rights Commission, Employment: Statutory Code of Practice. (Manchester: Equality and Human Rights Commission, 2011), sec. 13.12-13.13.
} 
... any Bishop intending to sponsor a transgendered person for a Bishops' Advisory Panel will certify that he has decided that he would be prepared to ordain and offer a Title to that person if during the course of training and formation she/he were deemed to have a vocation to ordained ministry. Bishops' Advisers [...] at which such a candidate was due to be considered would be given the opportunity of declaring in advance whether or not they could conscientiously recommend for training a transgender candidate. In such cases, either they or the candidate would be moved to another Panel. ${ }^{9}$

This provision, regarded as positive by Christina Beardsley, ${ }^{10}$ expressly allows the sponsorship and ordination of a trans candidate (though she notes the less certain position of clergy who wish to transition in post). I differ from Beardsley in seeing the discretion involved as problematic. A bishop may, but need not, sponsor a trans person - and if they do, they need to be prepared to ordain and offer a Title to that person. This provision does not apply to cis candidates. Nor could Bishops' Advisers declare that they could not conscientiously recommend a cis candidate qua cis candidate - but they may do so for trans candidates. There must, therefore, be something problematic about being a trans rather than a cis person. Rachel Mann was told, in her first bid for selection for priesthood, that 'the church was not quite ready for me'. ${ }^{11}$

It is impossible to know how many trans people might have put themselves forward for selection for ordination, were it not for the Church's differential treatment of trans people. It is impossible to know how many trans people might attend church, but for the Church's differential treatment of trans people. What Rachel Mann, writing of a specific church and sermon, describes as the 'absence of those this church considered unacceptable' ${ }^{12}$ could be more broadly applied to the Church as a whole.

\section{Marriage}

The Marriage Act 1949 s 5B (as amended by the Gender Recognition Act 2004) provides that: '(1) A clergyman is not obliged to solemnise the marriage of a person if the clergyman reasonably believes that the person's gender has become the acquired gender under the Gender

\footnotetext{
9 Church of England, "Diocesan Directors of Ordination Handbook Section 2 - Before the Bishops' Advisory Panel (Amended 29/04/16)" (Church of England, 2016), para. 17, https://www.churchofengland.org/clergy-office-holders/ministry/selection/ddos/ddo-handbook.aspx. ${ }^{10}$ Christina Beardsley, "Nudging towards Serendipity: The Church of England and Transsexual People," Crucible: The Christian Journal of Social Ethics July-September (2013): 17-24.

${ }^{11}$ Rachel Mann, Dazzling Darkness, 1st Edition (Glasgow: Wild Goose Publications, 2012), p. 62.

12 Ibid., p. 56.
} 
Recognition Act 2004.' Although legally, a trans person may have become a different sex from that on their original birth certificate, clergy may still refuse to perform the religious ceremony that would be extended to a cis couple. This amendment to the Marriage Act was the result of the Church's negotiation for conscientious objectors rather than inclusive principle: an accommodation of trans discrimination. ${ }^{13}$

These instances of institutional exclusion and discrimination take place against a backdrop of local churches where trans members of congregations experience condemnation, policing of behaviour, and ostracism, ${ }^{14}$ or more subtle pressures of acceptance so long as one is heterosexual or celibate post transition; ${ }^{15}$ where trans people accept restrictions on their potential ministries so as to not draw attention to themselves, ${ }^{16}$ or where trans people simply hold the shame of trans self-knowledge within, because to express it would not be acceptable. ${ }^{17}$ Avowedly Christian organisations such as Core Issues Trust provide a platform for Church of England priest Jules Gomes to proclaim the 'insanity' of 'gender lunacy'. ${ }^{18}$ Experiences that are simply normal to the cis person can be awful to the trans person, such as receiving communion before transition, in the wrong gender. ${ }^{19}$ Rejection from religious communities is one of the factors identified by Hopwood and Witten as contributing to serious mental health issues. ${ }^{20}$

\footnotetext{
13 Beardsley, "Nudging," p. 18.

${ }^{14}$ See, for example, Hannah Buchanan, "Christian Experience as a Transsexual," in Trans/Formations, ed. Marcella Althaus-Reid and Lisa Isherwood, Controversies in Contextual Theology (London: SCM Press,
} 2009), pp. 41-45.

${ }_{15}$ Mercia McMahon, "Trans Liberating Feminist and Queer Theologies," in This Is My Body: Hearing the Theology of Transgender Christians, ed. Christina Beardsley and Michelle O’Brien (London: Darton, Longman and Todd Ltd, 2016), p. 60.

${ }^{16}$ Chris Dowd, "Five Things Cis Folk Don't Know about Transfolk Because It Isn't on Trashy TV- My Right of Reply," in This Is My Body: Hearing the Theology of Transgender Christians, ed. Christina Beardsley and Michelle O’Brien (London: Darton, Longman and Todd Ltd, 2016), p. 104.

${ }^{17}$ Krzysztof Bujnowski, "Through the Wilderness," in Trans/Formations, ed. Marcella Althaus-Reid and Lisa Isherwood, Controversies in Contextual Theology (London: SCM Press, 2009), pp. 59-69.

${ }^{18}$ Jules Gomes, "Gender Is an Objective Fact, Not Some Batty Whim Summary," Core Issues Trust: Challenging Gender Confusion; Upholding Science \& Conscience, December 2016, http://www.coreissues.org/leading-stories-and-research/gender-is-an-objective-fact-not-some-batty-whim. ${ }^{19}$ Justin Edward Tanis, Trans-Gendered: Theology, Ministry, and Communities of Faith (Cleveland, Ohio: Pilgrim Press, 2003), p. 9.

${ }^{20}$ Ruben A. Hopwood and Tarynn M. Witten, "Spirituality, Faith and Religion: The TGNC Experience," in Affirmative Counseling and Psychological Practice with Transgender and Gender Nonconforming Clients, ed. 


\section{Omission}

In addition to the above instances of overt exclusion and disadvantageously differential treatment, trans people are also treated less favourably by omission. Elizabeth Stuart writes that 'depriving people of language with which to make sense of their experience is a particularly effective way of keeping them silent and disempowered'. ${ }^{21}$ This disadvantage by omission is present for trans people in at least two aspects. The first is the exclusion of trans people from the Church's understanding of the world, which is binary-focussed and privileges rigid categories of (cis) gender and (hetero) sexuality.

The second, following on from this primary invisibility, is a lack of rituals and services to celebrate significant life events of trans people, within the Church. ${ }^{22}$ Some individuals, such as myself, have benefitted from a Naming Service or similar, to celebrate and welcome a trans person in their new name and identity (a service offered at the discretion of the relevant clergyperson). This act of welcoming for a specific person, 'George', and the recognition of an important omission in the needs of trans people as part of the Church, is the prompting for the Diocesan Synod Motion put forward by Blackburn Diocese. ${ }^{23}$ Nationally commended liturgical materials would an important start, even if a clergyperson could refuse to perform such a ceremony, on grounds of conscience, as the Blackburn Motion suggests. ${ }^{24}$

\section{Theological approaches to trans issues}

Anneliese A. Singh and Lore M. Dickey, Perspectives on Sexual Orientation and Gender Diversity Series (Washington, DC: American Psychological Association, 2015), p. 217. See also the discussion of minority stress, below.

${ }^{21}$ Elizabeth Stuart, Daring to Speak Love's Name: Celebration of Friendship (London: Hamish Hamilton Ltd, 1992), p. 10, cited in Rachel Mann, Dazzling Darkness, 1st Edition (Glasgow: Wild Goose Publications, 2012), p. 77.

${ }^{22}$ Rob Clucas, "Religion," in Handbook on the Psychology of Sexuality and Gender, ed. Christina Richards and Meg John Barker (Houndmills, Basingstoke, Hampshire: Palgrave McMillan, 2015), pp. 447-63.

${ }^{23}$ Revd Chris Newlands, "General Synod, Diocesan Synod Motion: Welcoming Transgender People"

(General Synod, Church of England, June 2017), https://www.churchofengland.org/media/3996992/gs-

2071a-welcoming-transgender-people.pdf.

${ }^{24}$ Ibid., para. 18. 
The rationale for these less favourable treatments of trans people is to be found in the Church's submission to the Gender Recognition Bill (as was). In this document, the House of Bishops accepted that both positions below could properly be held:

a) some Christians concluded on the basis of Scripture and Christian anthropology, that concepts such as 'gender reassignment' or 'sex change' were really a fiction. Hormone treatment or surgery might change physical appearance, but they could not change the fundamental God-given reality of 'male and female He created them'.

b) others, by contrast, whilst recognising that medical opinion was not unanimous, were persuaded that there were individuals whose conviction that they were 'trapped in the wrong body' was so profound and persistent that medical intervention, which might include psychiatric, hormone, and surgical elements, was legitimate and that the result could properly be termed a change of sex or gender. ${ }^{25}$

Position a) rejects modern psychological and medical expertise, and more importantly, the experience and identities of trans people themselves. Theologians such as Martin Davie characterise gender dysphoria and transition as 'a result of sin', ${ }^{26}$ and understand people who transition as 'rejecting the goodness of God's creation of humanity as male and female in their particular case'. ${ }^{27}$ (Sian Taylder notes that "when our "sin"... is not one of "doing" but simply of "being" [...] love the sinner, hate the $\sin [. .$.$] becomes [...] a diktat of theological orthodoxy, a stick$ with which to beat those who refuse to toe the line. ${ }^{28}$ ) The proponents of position a) claim this superior knowledge thanks to their conservative interpretations of Scripture and humanity, which are somehow labelled 'Christian' in ways that position b) is not. This appeal to Scripture also claims a historic faithfulness, and thus pedigree, that obscures early and more recent affirming theologies within the Church. ${ }^{29}$

\footnotetext{
${ }^{25}$ House of Bishops, "HB(03)M1 Summary of Decisions 2003" (Church House, January 31, 2003).

${ }^{26}$ Martin Davie, Transgender Liturgies: Should the Church of England Develop Liturgical Materials to Mark. Gender Transition? (S.1.: LATIMER TRUST, 2017), p. 72.

${ }^{27}$ Ibid., p. 71.

${ }^{28}$ Sian Taylder, "Shot from Both Sides: Theology and the Woman Who Isn't Quite What She Seems," in Trans/Formations, ed. Marcella Althaus-Reid and Lisa Isherwood, Controversies in Contextual Theology (London: SCM Press, 2009), p. 71.

${ }^{29}$ Christina Beardsley, “Taking Issue: The Transsexual Hiatus in 'Some Issues in Human Sexuality," in This Is My Body: Hearing the Theology of Transgender Christians, ed. Christina Beardsley and Michelle O'Brien (London: Darton, Longman and Todd Ltd, 2016), pp. 69-79; John Boswell, Christianity, Social Tolerance,
} 
Moreover, by listing the conservative position first in the submission, position a) is implicitly more important/more acceptable as the Christian viewpoint. Position b) thus becomes less-than-properly-Christian (relying, as it does, on medical expertise and the experience of the trans community), in comparison to the supposedly Christian biblical and anthropological view of position a). Position b) is stigmatised in relation to position a) in the same way that trans people are stigmatised in relation to cis people..$^{30}$

Position b) is compatible with trans people's self-identifications, and the secular and majority expert medical and psychological view (though the 'trapped in the wrong body' narrative is a one-dimensional description of trans identities). But before considering the theology underpinning this stance, some further attention to its phrasing in the Church's submission is helpful.

Perhaps in 2003 it seemed appropriate to preface this view with the qualification 'whilst recognising that medical opinion was not unanimous...' Today, this proviso, though literally true in that medical opinion is not completely unanimous, is inappropriate. The overwhelming consensus in the Western world and beyond is that trans experiences are valid, and that transition is the appropriate course of action for trans people. ${ }^{31}$ Publicly-funded medical care is allocated to transition-specific treatment in the UK's National Health Service; medical insurance is a means for obtaining this treatment in countries without an NHS equivalent, such as the USA. In the psychiatric field, the latest edition of the Diagnostic and Statistical Manual of the American Psychiatric Association has changed terminology from 'Gender Identity Disorder' to 'Gender Dysphoria'; ${ }^{32}$ the forthcoming revision of the International Statistical Classification of Diseases and Related Health Problems (ICD 11) looks set to follow, with a new, nonstigmatising classification of 'gender incongruence'. ${ }^{33}$ (That a gender diagnosis is retained at all in

and Homosexuality: Gay People in Western Europe from the Beginning of the Christian Era to the Fourteenth Century (Chicago: Chicago University Press, 1980).

${ }^{30} \mathrm{My}$ thanks go to the anonymous reviewer of this article who asked me to emphasise this point.

${ }^{31}$ See further Beardsley's discussion in “Taking Issue: The Transsexual Hiatus in 'Some Issues in Human Sexuality."”

32 American Psychiatric Association, "Diagnostic and Statistical Manual of Mental Disorders (DSM-5),"

2013, http:// ebookcentral.proquest.com/lib/hull/reader.action?docID=1811753\&ppg=496.

33 Jack Drescher, “Gender Diagnoses and ICD-11,” Psychiatrics News, August 15, 2016, doi:10.1176/appi.pn.2016.8a15. 
these psychiatric manuals is essentially to ensure access to healthcare for trans people. ${ }^{34}$ ) Lawmakers around the world have enshrined trans people's rights into legislation - and continue to re-evaluate whether current legislation provides adequate protection and acknowledgment of and for trans people. ${ }^{35}$ Legal recognition has become a human right rather than an accommodation of medical necessity. ${ }^{36}$

Returning to position b), its resonance with trans-people's self-identifications is significant. Trans experience, or at least an attempt to theologise from an acceptance and understanding of trans experience, is emphasised by Chris Dowd, ${ }^{37}$ and especially by Mercia McMahon, who points to the need to 'weed out rich virgin moments's ${ }^{38}$, a reference to an experience of Marcella Althaus-Reed's, in which she missed the community with which she was trying to engage. ${ }^{39}$ Without understanding the trans person's experience of their body and gender, theologians such as Davie, ${ }^{40}$ or Oliver O'Donovan, ${ }^{41}$ misunderstand, fundamentally, the trans person as someone trying to separate body and mind/identity. Trans people themselves

${ }^{34}$ Jack Drescher, Peggy Cohen-Kettenis, and Sam Winter, "Minding the Body: Situating Gender Identity Diagnoses in the ICD-11," International Review of Psychiatry 24, no. 6 (December 2012): 568-77, doi:10.3109/09540261.2012.741575.

35 Women and Equalities Committee, “Transgender Equality” (London: House of Commons, 2015).

${ }^{36}$ Peter Dunne, "The Gender Recognition Act 2004: A Human Rights Analysis. Written Evidence Submitted by Peter Dunne to the Transgender Equality Enquiry,” October 5, 2015, http://data.parliament.uk/writtenevidence/committeeevidence.svc/evidencedocument/women-andequalities-committee/transgender-equality/written/22300.pdf.

${ }^{37}$ Dowd, "Five Things Cis Folk Don't Know."

${ }^{38}$ McMahon, “Trans Liberating Feminist and Queer Theologies,” p. 61.

39 As McMahon notes, ibid.:

From an outsider's perspective Mary might seem like a good symbol; she was a poor Palestinian woman ruled by an oppressive military dictatorship. This proved not to be the case for these poor Argentine women [her research participants] just four years after the end of military rule. Instead they interpreted Mary as rich via the local culture of processional statues. Likewise, a trans positive theology should check the interpretations with the trans community, and not just source its data there.

\footnotetext{
${ }^{40}$ Davie, Transgender Liturgies.

${ }^{41}$ Oliver O’Donovan, “Transsexualism and Christian Marriage," The Journal of Religious Ethics, 1983, pp. $135-162$.
} 
describe 'a divided self seeking to live more or less at peace with herself. ${ }^{42}$ Transitioning is 'a psychological and spiritual [procedure] about the trans person learning to become themselves after many years of self-repression and hiding, ${ }^{, 43}$ and 'a journey to authenticity, a deeply spiritual process [through which] I experienced a divine presence that was deeper and more profound than I had ever known. ${ }^{44}$

This focus on wholeness, and authenticity, is a recurring theme in trans theology (supported by psychological research into the positive aspects of a trans identity ${ }^{45}$ ). As Justin Edward Tanis writes about those who have not yet acknowledged their identity openly, or those who seek to hide it:

The attempt to live two lives, one known only to us and one that is seen and affirmed by the outside world, is dangerous and even deadly. The Spirit comes to lead us away from that danger and back to the search for authenticity. I believe that the pull of this identity is a sacred process, calling us to be more and more fully ourselves, as we were created to be. The quest is to discover who we were created to be and how we see ourselves in the world. $^{46}$

It is surely this becoming, this authenticity, that the Blackburn Motion seeks to honour.

Susannah Cornwall, writing on intersex issues, comprehensively highlights the heteronormative presuppositions inherent in Christian discourses, rooted in ideologies of complementarity, that condemn or refuse to accept trans realities. ${ }^{47}$ She also provides positive support for trans theology in the work of Gregory of Nyssa and others, arguing that 'apophatically influenced theologies, those who resist a finality of understanding and are

\footnotetext{
42 Mann, Daz:ling Darkness, 16.

${ }^{43}$ Dowd, "Five Things Cis Folk Don’t Know," 102.

${ }^{44}$ Tanis, Trans-Gendered, 4-5.

45 Ellen D.B. Riggle et al., "The Positive Aspects of a Transgender Self-Identification," Psychology and Sexuality 2, no. 2 (April 7, 2011): 147-58, doi:10.1080/19419899.2010.534490.

46 Tanis, Trans-Gendered, 26.

${ }^{47}$ Susannah Cornwall, Sex and Uncertainty in the Body of Christ: Intersex Conditions and Christian Theology, 1 edition (London ; Oakville Conn.: Routledge, 2010), chap. 4.
} 
grounded instead in a proactive unknowing about God, might, in fact, be important sites for solidarity about transgender. ${ }^{48}$

As mentioned above, conservative Christians selectively interpret Scripture. ${ }^{49}$ I have noted elsewhere that conservative Christian organisations conveniently choose to accept the views of modern psychology and medicine when the latter's views accord with the prejudices of the former. ${ }^{50}$ What is perhaps less often asked of conservatives is this: how would you feel if a powerful and vocal group of people in your world redefined Christianity, so that you were excluded? (One may even argue that, in their claim to the authority of tradition, which excludes past liberal voices, this is exactly what the 'traditionalists' have done to other theological viewpoints). The impact of refusing to accept the legitimacy - the reality - of a central part of someone's identity cannot be overstated.

Is there something about liberal theology that makes it more ready than conservative Christianities to engage with the reality of gender variant people, or the science, empirical evidence and theory that appear to confirm it? This is an important question, to which I can only sketch an answer here. First, it seems to me that liberal theology's commitment to engage with the excluded (whether socio-economically, sexually, or in terms of gender identity) is significant: it aims to take these voices seriously. Liberal theory also engages with the body, and being embodied. ${ }^{51}$ But perhaps the most striking characteristic for me is a more pervasive intellectual honesty: I find liberal theologians more likely to arrive at conclusions following a process of inquiry and reasoning, rather than 'justifying' a position that is already held.

${ }^{48}$ Susannah Cornwall, “Apophasis and Ambiguity: The 'Unknowingnes' of Transgender," in

Trans/Formations, ed. Marcella Althaus-Reid and Lisa Isherwood, Controversies in Contextual Theology (London: SCM Press, 2009), 16-17.

${ }^{49}$ For further discussion, see Beardsley, "Taking Issue: The Transsexual Hiatus in 'Some Issues in Human Sexuality," and Dowd, "Five Things Cis Folk Don't Know."

${ }^{50}$ Rob Clucas, "Sexual Orientation Change Efforts, Conservative Christianity and Resistance to Sexual Justice," Social Sciences 6, no. 2 (2017): 54, doi:10.3390/socsci6020054.

${ }^{51}$ Marcella Althaus-Reid, Indecent Theology, 1 edition (London: Routledge, 2000); Lisa Isherwood and Elizabeth Stuart, Introducing Body Theology (Sheffield: Continuum International Publishing, 1998); Lisa Isherwood, The Power of Erotic Celibacy: Queering Heterosexuality (London: T \& T Clark: a Continuum Imprint, 2006); Cornwall, Sex and Uncertainty in the Body of Christ; Susannah Cornwall, Theology and Sexuality (Norwich, UK: SCM Press, 2013); Adrian Thatcher, Making Sense of Sex, Modern Church Series (London: Society for the Promotion of Christian Knowledge, 2012). 


\section{Being disadvantaged}

What is the impact of being on the receiving end of discrimination? It is widely accepted among psychological professionals that minority stress (or marginalization stress) is the likely explanation for the higher prevalence of mental disorder among marginalized groups. ${ }^{52}$ Marginalization stress is the consequence of living with stressful stigma, prejudice and discrimination, rather than any underlying psychopathology of the group. ${ }^{53}$ Events or conditions that exceed the coping capacity of an individual may induce mental or somatic illness. ${ }^{54}$ Examples of stressors include dissonances with the majority culture, social structures, and norms, as well as straightforward prejudice. ${ }^{55}$ Meyer summarises the concept as follows:

minority stress is (a) unique- that is, minority stress is additive to general stressors that are experienced by all people, and therefore, stigmatized people are required an adaptation effort above that required of similar others who are not stigmatized; (b) chronic - that is, minority stress is related to relatively stable underlying social and cultural structures; and (c) socially based-that is, it stems from social processes, institutions, and structures beyond the individual rather than individual events or

\footnotetext{
${ }^{52}$ Ilan H. Meyer, "Minority Stress and Mental Health in Gay Men," Journal of Health and Social Behavior 36, no. 1 (March 1995): 38, doi:10.2307/2137286; Sharon S. Rostosky et al., "Same-Sex Couples' Decisions and Experiences of Marriage in the Context of Minority Stress: Interviews From a Population-Based Longitudinal Study," Journal of Homosexuality 63, no. 8 (August 2, 2016): 1019-40, doi:10.1080/00918369.2016.1191232; Michael King, "Possible Origins of the Increased Prevalence of Mental Disorder in LGBT People" (Science and Theology in Human Sexuality, St John's College, Durham University, 2016).

${ }^{53}$ Christina Richards and Meg John Barker, Sexuality and Gender for Mental Health Professionals: A Practical Guide (Los Angeles, London, New Delhi, Singapore, Washington DC: SAGE Publications Ltd, 2013), p. 80.

${ }^{54}$ Ilan H. Meyer, "Prejudice, Social Stress, and Mental Health in Lesbian, Gay, and Bisexual Populations: Conceptual Issues and Research Evidence.," Psychological Bulletin 129, no. 5 (2003): 675, doi:10.1037/00332909.129.5.674; Bruce P. Dohrenwend, "The Role of Adversity and Stress in Psychopathology: Some Evidence and Its Implications for Theory and Research," Journal of Health and Social Behavior 41, no. 1 (March 2000): 1-19, doi:10.2307/2676357.

${ }^{55}$ Meyer, "Prejudice, Social Stress, and Mental Health in Lesbian, Gay, and Bisexual Populations," pp. $675-76$.
} 
conditions that characterize general stressors or biological, genetic, or other nonsocial characteristics of the person or the group..$^{56}$

Discrimination may be individual - A labels and stereotypes B, and discriminates overtly against them - or structural, where 'accumulated institutional practices $[\ldots]$ work to the disadvantage of [...] minority groups even in the absence of individual prejudice or discrimination. ${ }^{57}$ These accumulated institutional practices include preferring to employ similar people to oneself, rather than expressly choosing not to employ someone perceived as different, and can be seen in manifestations of institutional racism. ${ }^{58}$

An example of the impact of marginalization stress can be found in Riggle et al.'s examination of the associations between legal recognition for LGB relationships and psychological distress or well-being. Participants in committed or legally recognized relationships reported less psychological distress and more well-being/meaningful lives than single LGB persons. Participants in a legally recognized relationship reported less internalized homophobia, fewer depressive symptoms, lower levels of stress, and more meaning in their lives than those in committed relationships. ${ }^{59}$

This distinction in well-being between LGB people in marriage-like informal relationships and those with legally recognized relationships demonstrates that legal recognition of the relationship enhances health. This has obvious negative implications for LGB people in jurisdictions where legal partnerships are not possible, and, I would argue, for functionally legal jurisdictions such as the Church. ${ }^{00}$ Although there is no outright ban on trans people marrying within the Church, s5B of the Marriage Act 1949 makes formal recognition of a trans person's relationship within the Church's functional legal system more precarious than for a cis person. It would be surprising if this had no impact on a trans person. Similarly, if legal recognition can be extrapolated to situations other than relationships, as seems reasonable, we ought to suppose

\footnotetext{
${ }^{56}$ Ibid., p. 676.

57 Bruce G. Link and Jo C. Phelan, "Conceptualizing Stigma," Annual Review of Sociology 27, no. 1 (2001): 372.

58 Ibid.

${ }^{59}$ Ellen D. B. Riggle, Sharon S. Rostosky, and Sharon G. Horne, "Psychological Distress, Well-Being, and Legal Recognition in Same-Sex Couple Relationships.," Journal of Family Psychology 24, no. 1 (2010): 82-86, doi:10.1037/a0017942.

${ }^{60}$ This point has also been made by Jack Drescher, in "History, Science and Politics of Homosexuality" (Science and Theology in Human Sexuality, St John's College, Durham University, 2016).
} 
that any instance of formal institutional recognition or prioritizing of cis people over trans people - such as the provisions in selection for ordination, employment, training and promotion - will result in negative health outcomes for trans people in that institution.

\section{Microaggressions}

My discussion so far has focussed on institutional and overt disadvantaging of trans people. Other overt manifestations of trans prejudice are possible - for example if a trans person were told they were not welcome in a particular congregation because they are trans. Presumably we would agree that this is straightforward prejudice. However, there are other means of communicating prejudice and discrimination 'expressed through seemingly meaningless and unharmful tactics, that deliver a hidden denigrating, hostile, or negative message about a person or a group': ${ }^{61}$ microaggressions.

Microaggessions are subtle, and thus challenging to decipher. They do not comprise a singular event - they are an accumulation of small injustices promoting an environment of hostility and confusion. Microaggressions are often communicated out of awareness (not consciously) by well-meaning and kind-hearted individuals, and are often explicable by nonprejudiced and acceptable reasons. ${ }^{62}$ Derald Wing Sue et al. explain that intended compliments such as 'you speak such good English', or interestedly asking an Asian American 'so where are you really from?' are both insulting and make the recipient feel like a perpetual outsider. ${ }^{63}$ Perpetrators of microaggressions regard them as innocuous and people who are not part of the minority group are unlikely to recognize them as slights. ${ }^{64}$ Charles R. Lawrence explains that this occurs in two ways: first, the human mind defends itself against guilt (e.g. at racism) by refusing to recognize its own unacceptable attitudes and beliefs. The Pilling Report's refusal to recognise the Church's homophobia and overlooking of its transphobia may be seen as examples of this. ${ }^{65}$

61 Kimber Shelton and Edward A. Delgado-Romero, "Sexual Orientation Microaggressions: The Experience of Lesbian, Gay, Bisexual, and Queer Clients in Psychotherapy.," Joumal of Counseling Psychology 58, no. 2 (2011): 210, doi:10.1037/a0022251.

${ }^{62}$ Shelton and Delgado-Romero, "Sexual Orientation Microaggressions."

${ }^{63}$ Sue et al., "Racial Microaggressions in Everyday Life," p. 73.

${ }^{64}$ Ibid., p. 72.

${ }^{65}$ Working Group on Human Sexuality, Report of The House of Bishops: Working Group on Human Sexuality. (London: Church House Publishing, 2013), https://www.churchofengland.org/our-views/marriage,family-and-sexuality-issues/human-sexuality/pilling-report.aspx. 
Second, the lessons of prejudice embedded in our culture are not experienced as lessons: 'they seem part of the individual's rational ordering of her perceptions of the world', and as such are tacit understandings that may not trouble our conscious awareness. ${ }^{66}$

Microaggressions take different forms: some are conscious, though most are not. ${ }^{67}$ Kimber Shelton and Edward A. Delgado-Romero suggest that the most dangerous kind, microinvalidations, are so because they deny the reality of the marginalized person or group, and impose an oppressive experience, insisting that this is the true reality. ${ }^{68}$ There are clear echoes here of position a) in the Church's submission on the Gender Recognition Bill.

Kevin L. Nadal et al. propose a taxonomy of microaggressions concerning trans people. ${ }^{69}$ The first type, (a), is the use of transphobic and/or incorrectly gendered terminology, such as incorrect pronouns ('he' for a trans woman; 'she' for a trans man) or denigrating language. Next is (b), the assumption of universal transgender experience, such as 'all trans women are prostitutes'. (c) follows: the exoticization, particularly sexual objectification, of trans people. Then (d), discomfort at or disapproval of transgender experience, that is disrespect of or discomfort at trans people because of their transness. After, (e), endorsement of gendernormative and binary culture or behaviours, followed by ( $\mathrm{f}$ ), the denial of the existence of transphobia, such as negating or minimizing the experiences of a trans person's reality of transphobia. Subsequently, position (g) is the assumption of sexual pathology or abnormality, for example assuming all trans people are hypersexual, or mentally ill. Afterwards comes (h), physical threat or harassment, and the pervasiveness of the threat of such. Microaggression (i) is the denial of individual transphobia, including blaming the trans person for being on the receiving end of prejudice. The next, (j), is the denial of bodily privacy, including staring at a trans person, and personal comments or questions about genitals and surgery that would not be asked of a cis person. Category $(\mathrm{k})$ comprises familial microaggressions, expressing disapproval. Finally, (l) systemic and environmental microaggressions, concerns systems and environments that impact

${ }^{66}$ Charles R. Lawrence, "The Id, the Ego, and Equal Protection: Reckoning with Unconscious Racism," Stanford Law Review 39, no. 2 (January 1987): 322-23, doi:10.2307/1228797.

${ }^{67}$ Sue et al., "Racial Microaggressions in Everyday Life."

${ }^{68}$ Shelton and Delgado-Romero, "Sexual Orientation Microaggressions," p. 211.

${ }^{69}$ Kevin L. Nadal, David P. Rivera, and Melissa J. H. Corpus, "Sexual Orientation and Transgender Microaggressions: Implications for Mental Health and Counseling," in Microaggressions and Marginality: Manifestation, Dynamics, and Impact, ed. Derald Wing Sue (Hoboken, New Jersey: John Wiley and Sons Inc., 2010), pp. 217-40; Nadal, Skolnik, and Wong, "Interpersonal and Systemic Microaggressions Toward Transgender People." 
negatively on all trans people interacting with that system or environment, for example the fear of violence when using public toilets, the profiling of or mistreatment of trans people by the criminal justice system, denial of adequate medical care (or the assumption that any medical problem must be transition-related) and barriers to official recognition of identity, such as changing the gender marker on one's passport. ${ }^{70}$

A consideration of the Church environment discussed above - without considering microaggressions perpetrated by individuals within the Church - yields the following:

Themes (a) - (c) are absent in these institutional examples. Discomfort at or disapproval of trans experience (d) is suggested in the Equality Act Schedule 9, trans candidates for ordination, and the 'conscience' provision for marriage. Endorsement of gender-normative behaviours (e) is likewise present in these examples: a person assigned female should act like a woman, and a person assigned male should act like a man. Denial of the existence of transphobia (f) can be seen in a number of instances: in Schedule 9, negative views about trans people are 'religious convictions', not prejudice; the power to refuse to marry a trans person in the Marriage Act 1949 s 5B is likewise a relevant religious concern. In respect of ordination, any problem concerning holiness and integrity of the candidate is situated in the trans person rather than the prejudice of the criteria. ${ }^{71}$

Theme (g), the assumption of some abnormality, probably underpins all my examples, but is especially salient for ordination. ${ }^{72}$ Holiness, integrity and so on are already criteria for all candidates. It can only be necessary to re-emphasize holiness and integrity in relation to trans candidates, if there is some belief that trans candidates are less holy and have less integrity than cis candidates. There is also the emphasis that ordained ministry is public: why so, unless there might be something inappropriate about a trans person qua trans person as a public representative of the Church?

The denial of individual transphobia (i) can be inferred from Schedule 9: the fault lies on the part of trans people for breaking 'religious' norms, not on the part of the institution or legal system for not accepting trans people's experiences as valid and proper. Concerning ordination, a Bishop's Advisor's refusal to recommend a trans candidate is a matter of conscience, not

70 Nadal, Skolnik, and Wong, "Interpersonal and Systemic Microaggressions Toward Transgender People," pp. 64-75.

${ }^{71}$ Church of England, “Diocesan Directors of Ordination Handbook Section 2 - Before the Bishops'

Advisory Panel (Amended 29/04/16).”

72 Ibid. 
prejudice. Regarding marriage: someone's being (or reasonably believed to be) trans removes the obligation to marry, so this is not prejudice on the part of the Church or legal system. Rather obviously, theme (l), systemic and environmental microaggressions, is satisfied in all three cases, because the threat of microaggressions is pervasive in the Church environment and the legal framework that supports this. Theme (j), the denial of bodily privacy, seems present in the statutory instrument that allows a person to disclose information about the previous legal sex of a person with a GRC in relation to marriage and membership of a religious organization. ${ }^{73}$

\section{The significance of differential treatment}

My argument is that the differential treatment of trans and cis people by the institutional Church (and sanctioned by the legal system) is harmful, and this harm ought to be recognized and addressed. The damage is not due to difference per se, but to the disadvantageous nature of the differences, and crucially, the microaggressive messages implicit in the trans-specific provisions. These messages point to trans people being different, disapproved of, and wrong.

The discretionary nature of these provisions is not an advantage. Discretion enables some trans people to succeed in their vocation or marriage, but it does not guarantee it. It makes the fate of a trans person within the Church uncertain. In the case of trans clergy, a lack of past discrimination does not guarantee the future. Discretion also foregrounds the microaggressive messages of 'different' and 'wrong': a trans person must inhabit and work in a world in which their exclusion and diminishment is legally and institutionally acceptable and accepted, even if not consistently applied, and in some cases contradicted. ${ }^{74}$

This, I suggest, is the real evil of trans people's situations in the Church: the accommodation of 'conscience' provisions and the presence of the view in the Church's submission on the Gender Recognition Bill that gender reassignment is really a fiction, gives

73 “The Gender Recognition (Disclosure of Information) (England, Wales and Northern Ireland) (No. 2) Order 2005,” para 4, accessed February 23, 2017, http://www.legislation.gov.uk/uksi/2005/916/article/4/made.

${ }^{74}$ Blackburn Diocesan Synod, "Diocesan Synod Motions: Welcoming Transgender People" (Church of England, April 2015), https://www.churchofengland.org/about-us/structure/general-synod/agendasand-papers/diocesan-synod-motions.aspx; Karen McVeigh, "Church of England to Consider Transgender Naming Ceremony," The Guardian, May 21, 2015, sec. Society, https://www.theguardian.com/society/2015/may/21/proposal-for-transgender-baptism-to-go-beforechurch-of-england. 
institutional legitimacy to prejudice. What the Church does not yet seem to have realized is that the inclusion of such voices, whilst soothing the conservatives, is not a neutral act. This inclusion does harm to trans people and to others who are marginalized on similar grounds. This accommodation sends the message that prejudice is acceptable, and that the conservatives' comfort is more important than a trans person's identity - and through the operation of marginalization stress, more important than a trans person's physical and mental health.

\section{Conclusion}

In this article, I have discussed the situation of trans people within the Church of England, outlining instances of legal and institutional discrimination, in relation to the Equality Act 2010 and employment, promotion and training, trans candidates for ordination, and marriage, with some development of the theological positions underpinning these. I have explained the impact of disadvantage and discrimination for minority groups with reference to Meyer's concept of minority or marginalization stress, and clarified the microaggressive messages contained in differential institutional treatment for trans people. I suggest that the harm done by Church discrimination against trans people is real and significant. Yet to date, the Church has preferred to accommodate conservatives voicing particular theological viewpoints among others, rather than face the truth of the hurt it inflicts on trans people. My plea is that the institutional Church recognizes that this accommodation of prejudice is unacceptable, and starts to cherish its marginalised clergy and congregants.

Rob Clucas lectures in Se(xuality), Gender and the Law at the University of Hull, and is Lecturer-in-Law in the School of Law and Politics. 